\title{
Endoskopik ultrasonografi rehberliğinde tümoral apse drenajı: Olgu sunumu
}

\author{
An endoscopic ultrasound-guided tumoral abscess drainage: A case report
}

Meltem ERGÜN, Vüsal ABDURRAHMANOV, Özlem SÖNMEZ, Başak ULUÇ

Yeditepe Üniversitesi Tip Fakültesi Gastroenteroloji Bilim Dal, Istanbul

Endoskopik ultrasonografi gastroenteroloji alanında giderek daha yaygin olarak kullanılmaktadır. Endoskopik ultrasonografi rehberliğinde yapılan girişimsel işlemlerden biri de apse drenajıdır. Ancak nekrotik tümoral implantların endoskopik ultrasonografi rehberliğinde drenajı henüz bildirilmemiştir. Tümoral kitlelerin seyrinde kemoterapötik ajanların etkisiyle tümoral kitlede nekroz gelismekte ve bu odak enfekte olabilmektedir. Bizim 65 yaşında metastatik over kanseri olan vakamızda, batın içindeki infekte nekrotik odaklara endoskopik ultrasonografi rehberliğinde drenaj yapılarak ve metalik stent yerleștirilerek, hastanın septik tablodan kurtulması sağlanmıștır.

Anahtar kelimeler: Endoskopik ultrasonografi, metastaz, drenaj

\section{GİRISS}

Endoskopik ultrasonografi (EUS) günümüzde tanısal amaçlı kullanımının yanında giderek daha çok terapötik işlemlerde kullanılmaya başlanmıştır. Pankreatik pseudokist drenajı, abdominal apse drenajı, safra kesesi drenajı bunlardan bazılarıdır (1,3). EUS rehberliğinde nekrotik tümöral implant drenajı ise literatürde bildirilmemiştir. Biz metastatik over kanseri tanısı konmuş, kemoterapi sonrası abdominal implantlarında nekrozis ve sonrasında apse gelişmiş ve sepsis kliniği ancak EUS rehberliğinde drenajla düzelmiş bir olguyu sunuyoruz.

\section{OLGU SUNUMU}

65 yaşında bayan hasta, bir yıl önce over Ca (Evre IV) tanısı almış ve kemoterapi tedavisi başlanmıştı. 9 kür kemoterapi alan hastanın son 2 haftadır karın ağrısı, bulantı, kusma ve ateş şikayetleri başladı. Hasta yatırılarak IV hidrasyon ve antibiyotik tedavisi başlandı. Ancak hastanın ateşi kontrol altına alınamiyordu ve C-reaktif protein (CRP) değerleri geniş spektrumlu antibiyotik tedavisine rağmen düşmemekteydi. Çekilen batın tomografisinde içinde hava-sıvı seviyeleri olan $9 \times 14 \mathrm{~cm}, 6 \times 5 \mathrm{~cm}$ ve $4 \times 5 \mathrm{~cm}$ boyutlarında tümör implantlar olduğu düşünülen lezyonlar izlendi (Resim 1). Yapılan endoskopik incelemede prepilorik antrumda yaklaşı $8-9 \mathrm{~cm}$ çapında diştan bası görünümü mevcuttu (Resim 2). Hastanın genel durum bozukluğu nedeniyle cerrahi işlem yapılamadı.
Currently, endoscopic ultrasonography is more commonly used in gastroenterology practices. An endoscopic ultrasonography-guided abscess drainage is one of the interventional procedures performed with endoscopic ultrasonography. However, an endoscopic ultrasonography-guided drainage of tumoral implants has not been reported yet. In the course of tumoral masses, tumoral necrosis develops under the influence of chemotherapeutic agents, and this focus can become infected. In our 65-year-old patient with a metastatic ovarian carcinoma, the infected necrotic foci within the abdomen were drained under the guidance of the endoscopic ultrasonography, a metallic stent placement was performed, and the patient recovered uneventfully.

Key words: Endoscopic ultrasound, metastasis, drainage

En büyük lezyona perkütan drenaj yapıldı. Ancak hastanın sepsis tablosu düzelmedi, $40{ }^{\circ} \mathrm{C}$ 'yi bulan ve düşürülemeyen ateşleri devam etti. EUS rehberliğinde drenaja karar verildi. EUS rehberliğinde yapilan incelemede yoğun solit komponenti olan anekoik apse izlendi (Resim 3). EUS FNA (19 G) ile girildikten sonra guide gönderilerek üzerinden balon dilatasyonu yapıldı ve $3 \mathrm{~cm}$ uzunluğunda metalik stent (diabola) yerleştirildi (Resim 4). Stent açılımını takiben mideye bol miktarda kahverengi apse içeriği ve nekrotik materyal boşaldı. Takip eden dönemde septik tablosu gerileyen ve apse boyutlarında ciddi küçülme saptanan hasta iki hafta sonra metalik stenti çekilerek taburcu edildi (Resim 5,6). Yaklaşık bir ay sonraki kontrolde hastanın ateşi yoktu ve CRP değeri normale inmiş ve $5 \mathrm{~kg}$ kadar kilo alımı olmuştu.

\section{TARTIŞMA}

EUS rehberliğinde pankreatik pseudokist drenajı, batın içi apse drenajı giderek gastroenteroloji pratiğinde daha sık olarak uygulanmaya başlamıştır (1-3). Geniş serilerde EUS rehberliğinde yapılan pankreatik pseudokist drenajının gerek cerrahi tedaviye, gerekse perkütan tedavilere daha üstün olduğu ortaya konmaktadır (4). Abse drenajlarında içeriğin nekrotik ve yoğun debris olması sebebiyle metalik stent kullanımı daha başarılı görülmektedir (5). EUS rehberliğinde 
safra kesesi drenajı da uygun olgularda oldukça başarılı sonuçlar vermektedir; bu olgularda da metalik stent uygulaması giderek daha sıklıkla uygulanmaktadır (6).

Metastatik soliter tümörü olan hastalarda batın içi tümöral implantlar oluşmakta ve kemoterapötik ajanlara yanıt vermektedir. Ne var ki, tümoral kitlede nekroz geliştikçe hastanın zayıflayan immün direncinin de etkisiyle, nekrotik odaklar infekte olabilmektedir. Bizim olgumuzda da daha önce soliter olan bu implantlar giderek nekrotik hale gelmiş ve sonra da apse odaklarına dönüşmüştür. Genel tıbbi praktikte alışılageldiği üzere apse=drenaj ilkesi bu durumda da geçerlidir. Bizim hastamızda da geniş spektrumlu antibiyotiklere rağmen hastanın sepsis tablosu iyileşmemiştir. Bu durumda tedavi alternatifleri cerrahi drenaj, perkütan drenaj ve

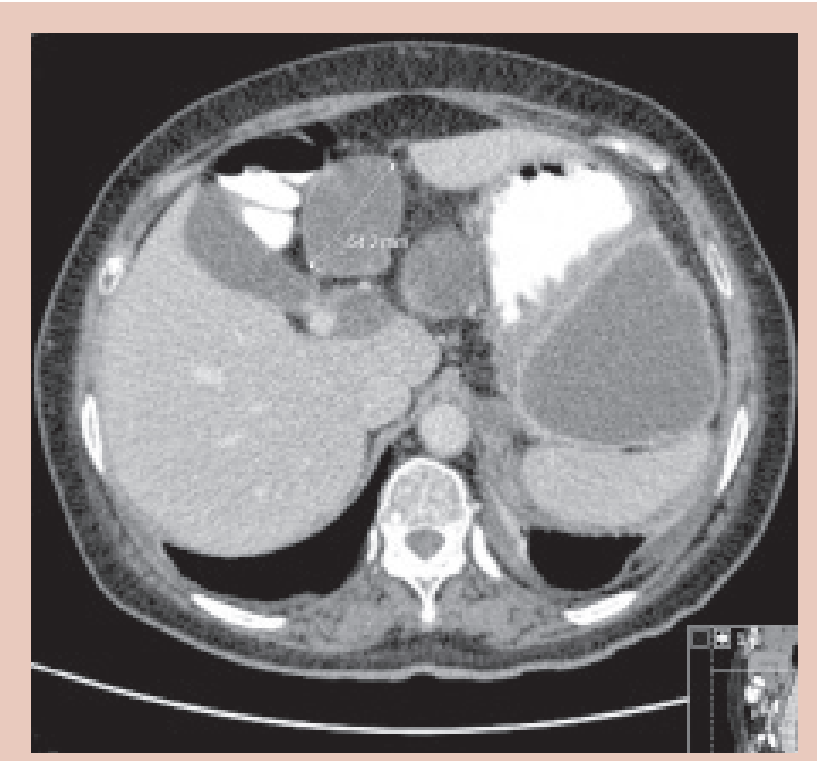

Resim 1. Abdominal $B T^{\prime}$ de tümoral nekrotik odak izleniyor.

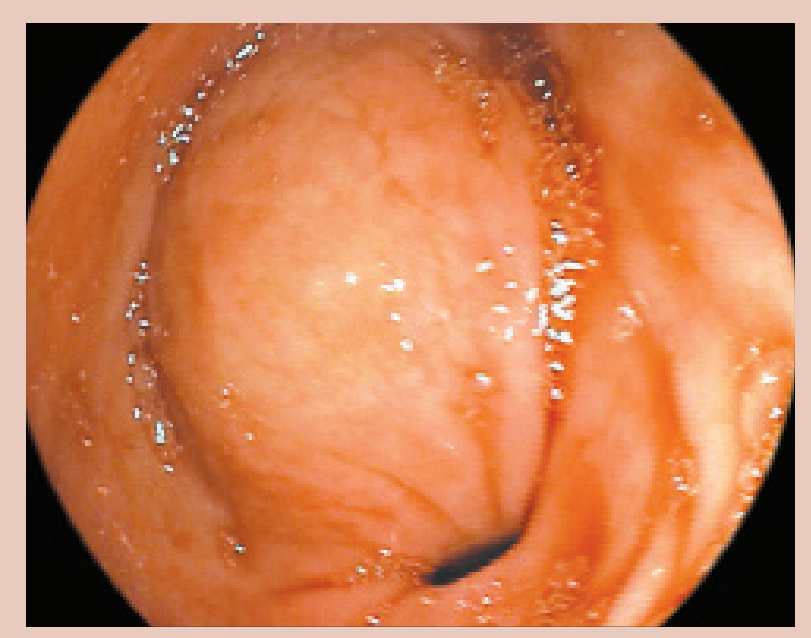

Resim 2. Endoskopik görünüm: Prepilorik antrum dıştan bası
EUS rehberliğinde drenaj olmaktadır. Cerrahi tedavi hastanın klinik durumunun ağır olması nedeniyle uygulanamamıştır. Perkütan tedavi hastamıza uygulanmış olsa da yoğun debris içeriği nedeniyle tedaviye olumlu bir katkı yaratamamıştır. EUS rehberliğinde metalik stent konmasiyla ancak yoğun debris içeriği drene edilebildiğinden, tedavi başarılı olmuştur. Hastanın septik tablosunda dramatik iyileşme sağlanmış ve kısa sürede ateşleri düşmüş, CRP yanıtı alınmıştır.

EUS rehberliğinde nekrotik tümoral implantlar başarılı şekilde drene edilebilir, drenaj sirasinda metalik stent konulması tedavi başarısı için gerekli görülmektedir. Literatürde benzer vaka olmaması nedeniyle bizim olgumuzun bu alanda ilk olduğunu düşünmekteyiz. EUS'un bu alanda deneyimli hekimlerce kullanımı başarılı ve güvenilir gözükmektedir.

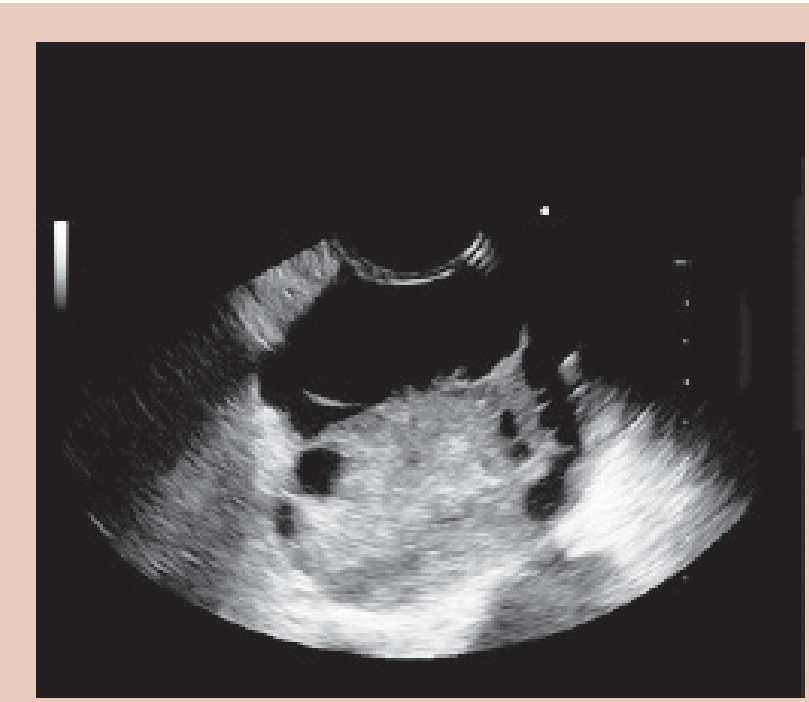

Resim 3. Endoskopik ulrasonografide içinde hava dansiteleri bulunan kistik nekrotik odak izleniyor.

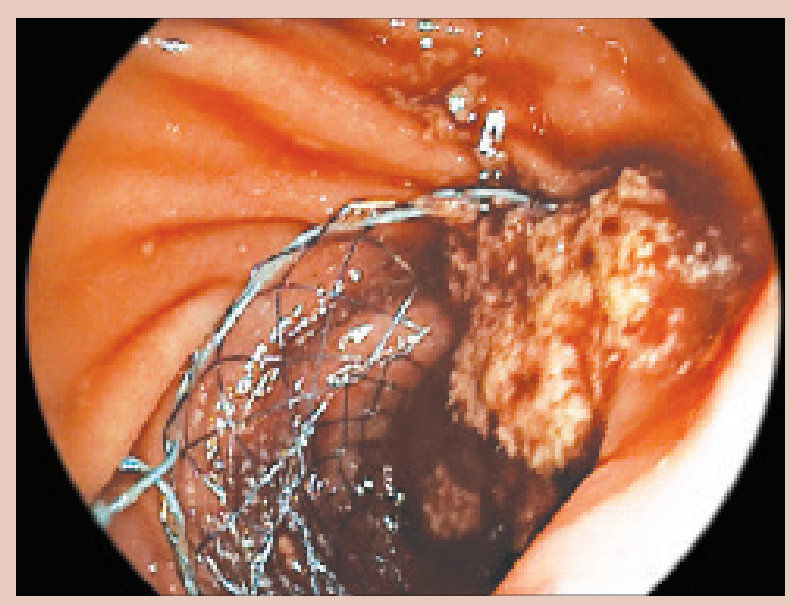

Resim 4. EUS rehberliğinde metalik stent yerleştirilmesini takiben mideye nekrotik debris drenajı izlenmektedir. 


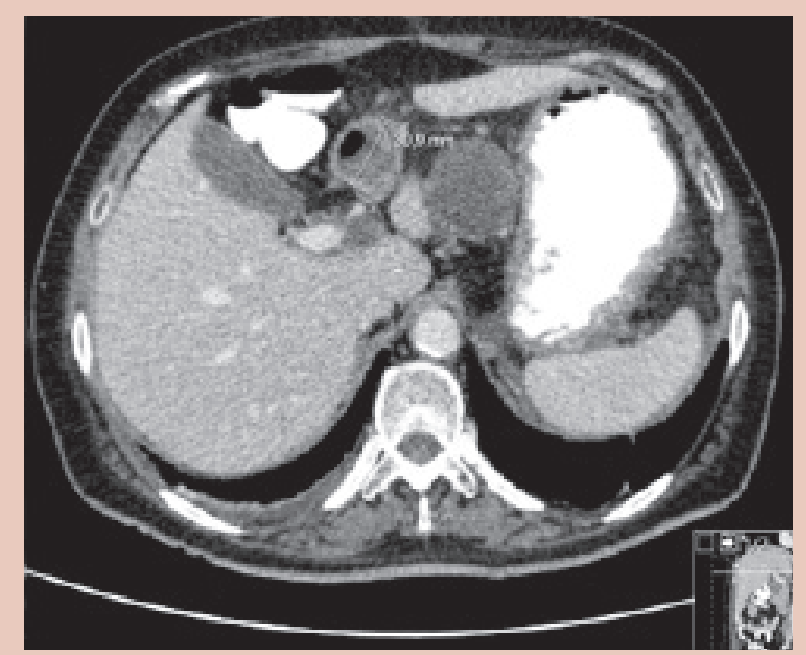

Resim 5. Drenaj sonrası apse çapında küçülme izleniyor.

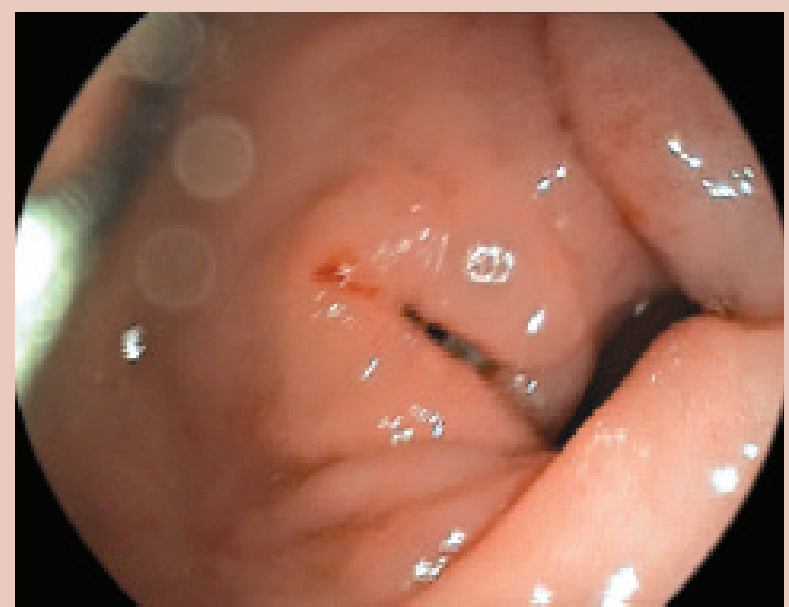

Resim 6. Metalik stent çekildikten sonra drenaj yerinin hemen kapandığı izlenmektedir.

\section{KAYNAKLAR:}

1. Javed S, Ho S. Endoscopic ultrasound guided perirectal abscess drainage using a novel lumen-apposing covered metal stent. Am J Gastroenterol 2016;111:1381.

2. Vilmann AS, Menachery J, Tang SJ, et al. Endosonography guided management of pancreatic fluid collections. World J Gastroenterol 2015;21:11842-53

3. Ogura T, Takagi W, Onda S, et al. Endoscopic ultrasound-guided drainage of a right liver abscess with a self-expandable metallic stent. Endoscopy. 2015;47(Suppl 1)UCTN:E397-8.

4. Kawakami H, Itoi T, Sakamoto N. Endoscopic ultrasound-guided transluminal drainage for peripancreatic fluid collections: where are we now? Gut Liver 2014;8:341-55. Epub 2014 Jul 1.

5. Kawakami H, Kuwatani M, Kawahata S, et al. Endoscopic ultrasound-guided pelvic abscess drainage using a dedicated, wide, flared-end, fully covered self-expandable metal stent. Endoscopy 2015;47(Suppl 1)UCT$\mathrm{N}:$ E265-6.

6. Irani S, Baron TH, Grimm IS, Khashab MA. EUS-guided gallbladder drainage with a lumen-apposing metal stent (with video). Gastrointest Endosc 2015;82:1110-5. Epub 2015 Jul 2. 